\title{
ANALISIS PENERAPAN MODEL PEMBELAJARAN KOOPERATIF TIPE TEAMS GAMES TOURNAMENT (TGT) DAN LEARNING TOGETHER (LT) TERHADAP HASIL BELAJAR SISWA SEKOLAH DASAR (SD)
}

\author{
Nia Fibria Nuriana \\ Program Studi Pendidikan Guru Sekolab Dasar, Universitas Nabdlatul Ulama Surabaya \\ Email:niafebriya@gmail.com
}

\begin{abstract}
Informasi Artikel Abstrak

Kata kunci:

Cooperative Learning

Teams Games Tournament (TGT)

Learning Together (LT)

Learning Outcomes

Diterima: 13-05-2020

Disetujui: 18-08-2020

Dipubikasikan: 26-10-2020

This study aims to determine the student learning outcomes using cooperative learning type Teams Games Tournament (TGT) and Learning Together (LT). This theoretical study is a systematic mapping study or study letarature. Student learning outcomes in the study of this theory are seen from the mathematics learning outcomes of elementary school (SD) students who use the cooperative learning model of the Teams Games Tournament (TGT) and Learning Together (LT) types. The results of the theoretical study show that there are differences in student learning outcomes that use the Teams Games Tournament (TGT) type of cooperative learning model, but they are not significant. While the results of the study of student learning outcomes theory using the cooperative learning model type Learning Together (LT) showed significant similarities. The results of the theoretical study can be concluded that in general student mathematics learning outcomes with the application of cooperative learning models of the Teams Games Tournament (TGT) and Learning Together (LT) experience a significant increase.
\end{abstract}

\section{PENDAHULUAN}

Salah satu ujung tombak pembangunan dan perkembangan kemajuan bangsa adalah pendidikan. Oleh karena itu, segala perbaikan dalam sektor pendidikan terus dilakukan. Model hingga media pembelajaran merupakan bagian dari pendidikan yang perlu diperhatikan untuk diperbaiki dan dikembangkan (Rachmadtullah et al. 2020). Pendidikan memiliki fungsi untuk melatih dan mewujudkan cita-cita secara aktif mengembangkan potensi dan kemampuan berpikir kritis seseorang. Dalam prakteknya, kualitas pendidikan dipengaruhi oleh beberapa sarana dan prasarana dalam proses pembelajaran serta kualitas kemampuan guru.

Pembelajaran merupakan proses interaksi antara peserta didik, pendidik/guru dan sumber belajar dalam proses belajar mengajar. Oleh karena itu, pembelajaran dijadikan sebagai bentuk bantuan untuk memperoleh ilmu pengetahuan serta membentuk sikap dan kepercayaan diri peserta didik. Apabila proses 
pelaksanaan proses pembelajaran di kelas terlaksana dengan baik, maka akan menghasilkan kualitas peserta didik yang baik pula (Setiawan, Rachmadtullah, and Iasha 2020). Oleh karena itu, dalam mengorganisasi suatu proses pembelajaran di kelas, guru memiliki peran dan fungsi yang besar dan aktif. Sedangkan peserta didik memiliki peran sebagai subjek belajar.

Penelitian Sukayati (2004: 1) pebelajaran matematika di Sekolah Dasar (SD) didominasi oleh pendekatan abstrak dengan metode ceramah dan pemberian tugas. Sangat jarang dijumpai guru yang merencanakan pembelajaran dengan tujuan untuk mengaktifkan siswa. Hal ini menunjukkan bahwa pembelajaran matematika pada umumnya masih terpusat pada guru, bukan apda siswa. Menurut Soedjadi (2001) dalam Warli (2013: 1) pada kurikulum matematika sekolah di Indonesia dan proses pembelajaran yang selama ini terpaku pada kebiasaan dengan urutan pembelajaran antara lain: (1) Diajarkan teori, (2) Diberikan contoh dan (3) Diberikan latihan soal. Kebiasaan pembelajaran tersebut menunjukkan bahwa guru selalu mendominasi kegiatan belajar mengajar, sedangkan siswa hanya menjadi pendengar dan pencatat. Hal tersebut mengakibatkan peserta didik kurang mandiri dan berani untuk menyampaikan pendapatnya, sehingga peserta didika akan bergantung pada bimbingan guru dan kurang mampu dalam menyelesaikan masalah matematika. Selain itu, pengetahuan yang dimiliki oleh peserta didik juga terbatas yaitu hanya pengetahuan yang diberikan guru saja. Hal ini akan melahirkan generasi-generasi pelajar yang gemar menyontek karena yang dinilai adalah hasil akhir bukan prosesnya. Hal tersebut bertolak belakang dengan tujuan pembelajaran pada kurikulum 2013 (K13) yang saat ini diterapkan di Indonesia.

Model pembelajaran Teams Games Turnament (TGT) merupakan salah satu model pembelajaran yang sesuai dengan kurikulum pendidikan 2013 (K13). Model pembelajaran tersebut membuat seluruh peserta didik berperan aktif dalam proses pembelajaran, karena setiap peserta didik akan saling menilai dan menjadi tutor untuk teman sebayanya. Selain itu, model pembelajaran ini mengandung unsur permainan, sehingga peserta didik dapat belajar sambil bermain. Model pembelajaran Teams Games Tumament (TGT) ini dapat membantu peserta didik menjadi lebih bersemangat dalam proses pembelajaran. Hal ini diharapkan dapat membantu siswa supaya lebih mudah memahami materi yang disampaikan oleh guru. Sehingga dapat disimpulkan bahwa model pembelajaran Teams Games Turnament (TGT) terbukti dapat meningkatkan prestasi dan mengubah sikap belajar siswa menjadi lebih baik dalam suatu proses pembelajaran. Pada model pembelajaran Teams Games Tumament (TGT) ada lima langkah utama yang harus dicapai dalam suatu proses pembelajaran yaitu: presentasi/pengarahan, belajar kelompok, permainan, pertandingan, dan mengorganisasi kelompok.

Selain itu, salah satu model pembelajaran yang juga dapat meningkatkan keaktifan siswa dalam pembelajaran adalah model pembelajaran kooperatif Learning Together (LT). Menurut Slavin (2015: 48-56) model Learning Together (LT) memiliki proses pembelajaran yang melibatkan tanggung jawab setiap siswa yang konsisten dalam menunjukkan pengaruh positif yang signifikan. Pada proses pembelajaran kooperatif tipe Learning Together (LT) terbukti menghasilkan proses pembelajaran yang lebih efektif dibandingkan dengan model pembelajaran individualistik. Fathurrohman (2015:68) menyatakan bahwa pada model pembelajaran kooperatif tipe Learning 
Together (LT) terjadi pembentukan kelompok-kelompok di kelas beranggotakan siswa-siswa yang beragam kemampuan mulai dari yang terendah hingga yang tertinggi. Setiap kelompok bekerja sama untuk menyelesaikan tugas yang diberikan oleh guru. Satu kelompok hanya menerima dan mengerjakan satu Lembar Kerja Peserta Didik (LKPD). Penilaian didasarkan pada hasil kerja setiap kelompok. Melalui model pembelajaran kooperatif tipe Learning Together (LT), setiap siswa minta untuk menilai kinerja kelompoknya. Pembelajaran yang menggunakan model kooperatif tipe Learning Together (LT) dilakukan dengan setiap kelompok diberi bahan diskusi untuk dikerjakan dan didiskusikan bersama semua anggota kelompoknya, sehingga setiap siswa harus aktif berpartisipasi menuangkan ide, gagasan dan pengetahuannya untuk menyelesaikan tugas yang masalah yang diberikan. Selain itu, melalui pembelajaran kooperatif tipe Learning Together (LT) siswa dibiasakan untuk bekerja sama dengan teman satu kelompoknya. Siswa juga dilatih untuk memiliki rasa percaya diri dan berani menyampaikan pendapat di depan orang lain, karena hasil diskusi yang telah dikerjakan akan dipresentasikan di depan kelas dan didengarkan oleh teman satu kelasnya. Setiap kelompok harus bisa menunjukkan kekompakan dan pengetahuan mereka dengan baik. Slavin (2015: 250) menyatakan bahwa Learning Together (LT) menekankan empat unsur, yaitu (1) interaksi tatap muka, (2) interpendensi positif, (3) tanggung jawab individual, (4) kemampuan-kemampuan interpersonal dan kelompok kecil.

Berdasarkan uraian di atas, model pembelajaran kooperatif tipe Teams Games Tumament (TGT) dan Learning Together (LT) memiliki langkah dan penerapan yang berbeda. Sehingga penulis menganalisis penerapan model pembelajaran kooperatif tipe Teams Games Turnament (TGT) dan Learning Together (LT) terhadap hasil belajar matematika siswa.

\section{METODE}

Kajian teori ini merupakan studi pemetaan sistematis atau study letarature terkait analisis penerapan model pembelajaran kooperatif tipe Teams Games Tumament (TGT) dan Learning Together (LT) terhadap hasil belajar matematika siswa Sekolah Dasar (SD).

\section{HASIL DAN DISKUSI}

\section{Pembelajaran Kooperatif}

Model pembelajaran kooperatif dapat melatih siswa untuk mendengarkan pendapat orang lain dan merangkum topik yang disampaikan dalam bentuk tulisan. Tugas-tugas kelompok yang diberikan dapat memacu para siswa untuk bekerja sama dan saling membantu antar siswa dalam berbagi pengetahuan baru yang dimiliki. Tim MKPBM (2001:218) menyatakan, “Cooperative learning mencakupi suatu kelompok kecil siswa yang bekerja sebagai sebuah tim untuk menyelesaikan sebuah masalah, menyelesaikan suatu tugas, atau mengerjakan sesuatu untuk tujuan bersama lainnya".

Karli, H dan Margaretha, S. Y (2002:70) mengatakan bahwa model pembelajaran kooperatif adalah suatu strategi belajar mengajar yang menekankan pada sikap atau perilaku saling bekerja sama dengan anggota 
kelompok. Slavin (dalam Wardani, Sri 2002:16) menyatakan bahwa pembelajaran kooperatif adalah model pembelajaran dengan aktivitas belajar dan bekerja secara berkelompok-kelompok kecil dan berkolaborasi antar anggota kelompok yang terdiri dari empat sampai enam orang dengan kemampuan siswa yang heterogen.

Berdasarkan beberapa pendapat di atas, dapat disimpulkan bahwa belajar matematika dengan menggunakan model pembelajaran kooperatif sangat tepat diterapkan untuk meningkatkan keberanian siswa dalam mengemukakan pendapatnya, dapat menghargai pendapat orang lain, dan mendorong siswa untuk bekerja sama dalam menyelesaikan masalah. Keberhasilan dalam kelompok sangat dipengaruhi oleh partisipasi dari setiap anggota kelompok. Oleh karena itu belajar dengan menggunakan model pembelajaran kooperatif sangat baik untuk dilaksanakan karena dapat mendorong siswa untuk bekerja sama dan saling tolong menolong dalam mengatasi permasalahan yang dihadapi.

Karli dan Margaretha (2002:71) berpendapat bahwa karakteristik pendekatan model pembelajaran kooperatif ada empat antara lain: (a) Individual Accountability, artinya setiap individu dalam kelompok memiliki tanggung jawab untuk menyelesaikan masalah yang dihadapi oleh kelompok, sehingga keberhasilan kelompok sangat ditentukan oleh tanggung jawab setiap anggota, (b) Social Skill, meliputi kehidupan sosial, kepekaan sosial dan mendidik siswa untuk menumbuhkan rasa lebih mementingkan kepentingan kelompok daripada kepentingan pribadinya. Keterampilan ini mengajarkan siswa untuk belajar memberi, mengambil dan menerima tanggung jawab, menghormati dan menghargai hak orang lain serta membentuk kesadaran sosial, (c) Positive Interdependen, merupakan sifat yang secara positif menunjukan saling ketergantungan satu sama lain. Keberhasilan dalam kelompok sangat ditentukan oleh peran aktif setiap anggota kelompok. Hal ini dikarenakan setiap anggota kelompok dianggap memiliki kontribusi yang berharga. Sehingga siswa dapat berkolaborasi bukan untuk berkompetensi, dan (d) Group Processing, proses perolehan jawaban dari suatu permasalahan dikerjakan oleh seluruh anggota kelompok secara bersama-sama.

Pembelajaran dengan model kooperatif menuntut siswa untuk saling bekerja sama demi mencapai hasil belajar yang maksimal. Model pembelajaran kooperatif juga memandang bahwa keberhasilan dalam belajar bukan hanya diperoleh dari guru, melainkan dari pihak lain yang terlibat dalam proses pembelajaran seperti teman sebaya. Dapat disimpulkan bahwa keberhasilan belajar bukan hanya ditentukan oleh kemampuan setiap individu, melainkan diperoleh secara bersama-sama dalam kelompok kecil dengan struktur pengorganisasian yang baik.

\section{Pembelajaran Kooperatif Tipe Teams Games Toumament (TGT)}

Model pembelajaran Teams Games Toumament (TGT) merupakan salah satu model pembelajaran kooperatif yang menggunakan kerja kelompok dengan anggota siswa dengan kemampuan yang heterogen dan pertandingan mingguan berupa permainan akademik yang dimainkan oleh siswa dengan anggota kelompok lain 
untuk menambahkan poin bagi skor kelompoknya. Dalam model pembelajaran tersebut, siswa memiliki peran sebagai tutor temannya sendiri dan mengandung unsur permainan yang menyenangkan (Slavin, 2011: 13).

Menurut Slavin model pembelajaran kooperatif tipe Teams Games Tournament (TGT) memiliki beberapa tahapan antara lain tahap pengajaran, belajar kelompok, permainan, pertandingan, dan penghargaan kelompok. Tahapan yang dilaksanakan dalam model pembelajaran ini mengandung unsur permainan akademik yang dapat meningkatkan keaktifan siswa dalam kegiatan pembelajaran.

Selain itu, Yolagel Dili dan Arikan (dalam Tyasning dkk., 2012: 27) menyatakan bahwa permainan akademik yang diberikan pada proses pembelajaran di kelas, dapat meningkatkan motivasi dan minat belajar siswa. Sehingga tujuan diterapkannya model pembelajaran kooperatif tipe Teams Games Toumament (TGT) dengan permainan akademik tidak lain adalah untuk meningkatkan aktivitas dan hasil belajar siswa.

Slameto (dalam Hanggarwati, 2016: 10) menyatakan bahwa sebaiknya guru memberikan kesempatan kepada siswa untuk menyelidiki, mengamati, mempelajari, dan mencari penyelesaian masalah secara mandiri. Proses pembelajaran tersebut dapat menumbuhkan semangat belajar siswa dan berdampak pada semakin baiknya hasil akhir yang diperoleh siswa. Sanjaya (2006: 239) juga mengemukakan bahwa pembelajaran kooperatif merupakan kegiatan belajar siswa yang dilakukan secara berkelompok untuk mencapai tujuan belajar. Sedangkan pembelajaran kooperatif tipe Teams Games Tournament (TGT) merupakan pembelajaran yang membentuk siswa menjadi kelompok-kelompok dan memainkan permainan akademik.

Menurut Shoimin, (2014: 203) model pembelajaran kooperatif tipe Teams Games Toumament (TGT) merupakan tipe model pembelajaran kooperatif yang mudah untuk dilaksanakan karena tidak memperhatikan kemampuan sikap siswa dan melibatkan peran setiap siswa untuk menjadi tutor sebaya dan memiliki unsur permainan serta reinforcement. Dalam penerapan model pembelajaran kooperatif tipe Teams Games Toumament (TGT) menghasilkan siswa yang aktif dan memiliki sikap belajar yang lebih tenang serta dapat meningkatkan rasa tanggung jawab, kerjasama, persaingan antar kelompok secara sehat, dan ketertiban dalam belajar, sehingga diharapkan dapat mengubah hasil belajar siswa menjadi lebih baik. Berdasarkan uraian pendapat di atas, model pembelajaran kooperatif tipe Teams Games Toumament (TGT) yang diterpakan dalam proses pembelajaran diharapkan dapat meningkatkan hasil belajar siswa.

\section{Hasil Belajar Matematika Siswa Yang Memperoleh Model Pembelajaran Kooperatif Tipe Teams Games Tournament (TGT)}

Menurut Bloom (dalam Suprijono 2009) hasil belajar merupakan hasil yang diperoleh oleh siswa setelah melakukan proses pembelajaran. Hasil tersebut mencakup nilai kognitif yang dapat dilihat dari hasil evaluasi pekerjaan siswa, sedangkan nilai afektif dapat dilihat dari angket yang berupa sikap dan rasa tanggung jawab, dan nilai psikomotorik dapat dilihat dari aspek keterampilan. 
Hasil belajar matematika siswa yang memperoleh model pembelajaran kooperatif tipe Teams Games Tournament (TGT) berdasarkan penelitian Cahyaningsih (2017: 1) menunjukkan adanya pengaruh model pembelajaran kooperatif tipe Teams Games Tournament (TGT) terhadap hasil belajar matematika siswa Sekolah Dasar (SD) pada aspek kognitif dan psikomotorik. Hal tersebut terlihat pada hasil evaluasi dan presentasi siswa yang lebih baik antara kelas kontrol dan kelas eksperimen. Sedangkan hasil belajar pada aspek afektif, diperoleh antara angket kelas kontrol dan kelas eksperimen memiliki kesamaan. Sehingga menunjukkan tidak adanyanya perubahan pada aspek afektif. Jadi, penelitian tersebut dapat bahwa tidak terdapat pengaruh model pembelajaran kooperatif tipe Teams Games Toumament (TGT) terhadap hasil belajar matematika pada aspek afektif.

Selain itu, penelitian serupa juga dilakukan oleh Mulyati dan Guntarsih (2018: 1) yang menunjukkan bahwa adanya peningkatan hasil belajar siswa Sekolah Dasar (SD) dengan nilai rata-rata siswa satu kelas sebelum memperoleh tindakan adalah 6,8 dan meningkat menjadi 7,5 pada siklus I, kemudian pada siklus II meningkat lagi menjadi 8,05. Peningkatan hasil belajar siswa pada kelas tersebut terjadi karena selama model pembelajaran kooperatif tipe Teams Games Turnamen (TGT) diterapkan, siswa lebih termotivasi dan aktif dalam proses pembelajaran.

Penelitian Nazamim (2013) menunjukkan adanya peningkatan hasil belajar siswa Madrasah Ibtidaiyah (MI). Hal tersebut terlihat dari peningkatan nilai rata-rata kelas dari hasil belajar siklus I ke siklus II adalah 17,7 poin. Pada siklus I nilai rata-rata dalam kelas yang adakan diberi tindakan adalah 66,4 kemudian pada siklus II nilai rata-rata dalam kelas tersebut meningkat menjadi 84,1. Selain itu, nilai siswa yang memenuhi Kriteria Ketuntasan Minimal (KKM) juga mengalami peningkatan. Hal tersebut terlihat pada hasil belajar siklus I yaitu jumlah siswa yang memenuhi Kriteria Ketuntasan Minimal (KKM) sebanyak 87\% dari jumlah siswa keseluruhan yang menjadi subjek penelitian dengan nilai rata-rata kelas 66,4 dan hasil belajar siklus II jumlah siswa yang memenuhi Kriteria Ketuntasan Minimal (KKM) mencapai 100\% dari jumlah siswa keseluruhan yang menjadi subjek penelitian dengan nilai rata-rata kelas 84,1 .

Penelitian Fida Rahmatika Hadi tahun 2017 dengan judul "Penerapan Model Teams Games Turnamen (TGT) Dalam Pembelajaran Matematika Untuk Meningkatkan Hasil Belajar Siswa Kelas IV SDN Taman 3 Madiun” FKIP Universitas PGRI Madiun. Temuan penelitian ini adalah penerapan Strategi Teams Games Turnamen (TGT) dalam pembelajaran matematika dengan perwujudan lima langkah penerapan model Teams Games Turnamen (TGT) antara lain: presentasi kelas, kerja tim/kelompok, permainan, turnamen, dan penghargaan tim/kelompok. Model Teams Games Turnamen (TGT) dapat meningkatkan hasil belajar siswa kelas IV Sekolah Dasar (SD). Peningkatan hasil belajar ini terlihat dari adanya peningkatan hasil tes siswa yang dilaksanakan pada tiap akhir siklus. 
Penelitian Joeni Asih tahun 2017 dengan judul "Meningkatkan Motivasi Belajar Matematika Melalui Model Pembelajaran Kooperatif Tipe Teams Games Tumamen (TGT) Siswa kelas VI SD Negeri 02 Teluk Nilap Kubu Babussalam” FKIP Universitas Riau. Temuan dalam penelitian ini adalah model Teams Games Turnamen (TGT) dapat meningkatkan motivasi belajar siswa pada mata pelajaran Matematika siswa kelas VI SD Negeri 002 Teluk Nilap Kubu Babussalam. Penelitian tersebut mendapati bahwa sebelum siswa diberikan tindakan, motivasi belajar mereka mencapai rata-rata persentase 36,2\% dan berada pada interval $0-40 \%$. Sedangkan pada siklus pertama pertemuan pertama disebutkan bahwa motivasi belajar siswa hanya mencapai rata-rata 51,4\% dan berada pada interval 40\%-55\%, hal ini tergolong cukup tinggi. Pada siklus I pertemuan kedua motivasi belajar siswa terjadi peningkatan mencapai rata-rata persentase $56,9 \%$ dan berada pada interval 40-55\%, hal ini tergolong cukup tinggi. Pertemuan pertama pada siklus II motivasi belajar siswa mengalami peningkatan kembali hingga mencapai rata-rata 71\% dan berada pada interval 56\%-75\%, hal ini tergolong tinggi. Pada pertemuan kedua siklus II motivasi belajar siswa mengalami peningkatan hingga mencapai nilai rata-rata persentase $83,4 \%$ dan berada pada interval $76-100 \%$, hal ini dapat dikategorikan sangat tinggi. Sehingga berdasarkan kedua siklus yang telah dilakukan tersebut, penelitian tersebut menyimpulkan bahwa penggunaan model Teams Games Turnamen (TGT) dapat mempengaruhi aktivitas belajar siswa menjadi lebih aktif dan adanya peningkatan motivasi dan hasil belajar siswa.

\section{Pembelajaran Kooperatif Tipe Learning Together (LT)}

Learning together (LT) adalah pembelajaran kooperatif yang dilakukan dengan cara mengelompokkan siswa yang memiliki tingkat kemampuan yang berbeda (Johnson and Johnson, 1994). Dalam model pembelajaran kooperatif tipe Learning together (LT) guru berperan untuk mengawasi kelompok-kelompok yang telah dibentuk berdasarkan pada lima komponen pembelajaran kooperatif antara lain interdependensi positif, akuntabilitas individu, interaksi langsung, keterampilan-keterampilan sosial, dan pemrosesan kelompok.

Menurut Slavin (2010) pembelajaran kooperatif tipe Learning Together (LT) lebih mengutamakan empat unsur bagian dalam proses pembelajarannya yaitu: (1) Interaksi tatap muka yaitu siswa bekerja dalam kelompok yang beranggotakan empat sampai lima orang, (2) Interdependensi positif yaitu siswa bekerja sama untuk mencapai tujuan kelompok, (3) Tanggung jawab individual yaitu siswa bahwa secara individual dapat menguasai materi yang diberikan, (4) Kemampuan interpersonal dan kelompok kecil yaitu siswa diajari tentang efektifitas dalam bekerja sama dan mendiskusikan seberapa baik dalam bekerja untuk mencapai tujuan kelompok. Adapun sintaks metode pembelajaran tipe Learning Together (LT) yang dikembangkan oleh David dan Roger Johnson (dalam Slavin, 2009: 25) antara lain: (1) Membagi siswa menjadi beberapa kelompok, (2) Setiap kelompok memiliki anggota dengan kemampuan yang heterogen, (3) Setiap kelompok mengerjakan tugas yang telah diberikan secara bersama-sama, (4) Guru memberikan nilai dari hasil pekerjaan setiap kelompok, (5) Guru memberikan penghargaan kepada kelompok terbaik, dan (6) Penghargaan dapat berupa pujian atau bentuk lain yang bersifat mendidik sehingga dapat meningkatkan semangat belajar dan prestasi siswa. 


\section{Hasil Belajar Matematika Siswa Yang Memperoleh Model Pembelajaran Kooperatif Tipe Learning Together (LT)}

Berdasarkan hasil penelitian Bukunola, J., \& Idowu, D. (2012) pembelajaran kooperatif tipe Learning Together (LT) lebih efektif untuk meningkatkan prestasi belajar dan rasa percaya diri dalam menyampaikan pendapat siswa. Selain itu, enelitian Özsoy dan Nazlı Yildi (2014:53) yang berjudul The Effect OfLearning Together Technique Of Cooperative Learning Method On Student Achievement In Mathematics Teaching 7th Class Of Primary School menunjukkan bahwa model pembelajaran menggunakan Learning Together (LT) lebih efektif daripada model pembelajaran tradisional pada pembelajaran matematika. Hal tersebut dapat dibuktikan dengan nilai rata-rata kelas dengan menggunakan metode pembelajaran kooperatif meningkat sebesar 1.11 sedangkan nilai rata-rata kelas yang menggunakan metode pembelajaran tradisonal meningkat hanya 0.41. Sehingga penelitian Özsoy dan Nazlı Yildi menyimpulkan bahwa model pembelajaran menggunakan Learning Together (LT) dapat meningkatkan hasil belajar siswa.

Penelitian Unamba E. C., (2015:63) menunjukkan bahwa prestasi belajar matematika menggunakan model pembelajaran Learning Together (LT) lebih efektif daripada model pembelajaran tradisional pada pembelajaran matematika. Hal ini terbukti dengan hasil uji-t diperoleh $t_{\text {hitung adalah } 8.776 \text { dan harga }}$ $t_{\text {tabel }}$ adalah 2.000 dengan taraf signifikansi 0.05 . Hal ini berarti harga $t_{\text {hitung }}$ lebih besar dari harga $t_{\text {tabel }}$ $\left(t_{\text {hitung }}>t_{\text {tabel }}\right)$. Sehingga hasil belajar matematika siswa yang menggunakan model pembelajaran Learning Together (LT) mengalami peningkatan.

Penelitian Setianingsih (2012:14-15) menunjukkan bahwa model pembelajaran kooperatif tipe Learning Together (LT) dapat meningkatkan keaktifan siswa dalam kegiatan belajar mengajar dan hasil belajar siswa. Hal tersebut dibuktikan pada siklus I diperoleh nilai rata-rata kelas adalah 57,82 dari 46 siswa dan yang memperoleh nilai diatas Kriteria Ketuntasan Minimal (KKM) hanya ada 26 siswa. Pada siklus II menunjukkan adanya peningkatan rata-rata kelas di atas Kriteria Ketuntasan Minimal (KKM) yaitu 79,56 dari 46 siswa dan yang memperoleh nilai di atas Kriteria Ketuntasan Minimal (KKM) ada 42 siswa.

Penelitian Rahayu (2015:170-171), menunjukkan bahwa model pembelajaran Learning Together (LT) dapat meningkatkan hasil dan prestasi belajar siswa. Hal ini terbukti dengan peningkatan ketuntasan belajar siswa dalam setiap siklus, pada siklus I diperoleh nilai rata-rata kelas adalah 67,28 dan siswa yang memperoleh nilai di atas Kriteria Ketuntasan Minimal (KKM) sebanyak 15 siswa dari keseluruan jumlah 22 siswa, sehingga persentase ketuntasan belajar sebesar 68,18\%. Pada siklus II dengan nilai rata-rata kelas 74,81 dan siswa yang berhasil mencapai ketuntasan sebanyak 17 dengan persentase ketuntasan belajar sebesar 81,48\%.

Penelitian Irawati (2016) menunjukkan keefektifan model pembelajaran Learning Together (LT) didasarkan pada uji keefektifan hasil belajar yang menunjukan bahwa $t_{\text {hitung }}$ tes akhir $(2.2149765502)>t_{\text {tabel }}$ (2.021), peningkatan hasil belajar $t_{\text {hitung }}(4.413794)>t_{\text {tabel }}$ (1.705), dan peningkatan hasil belajar 
ternormalisasi $t_{\text {hitung }}(5.155301)>t_{\text {tabel }}(1.705)$, sehingga uji hipotesis keefektifan pembelajaran tersebut menolak Ho, yang artinya model pembelajaran Learning Together (LT) lebih efektif dan meningkatkan hasil belajar siswa.

\section{KESIMPULAN}

Hasil penelitian yang dilakukan oleh Cahyaningsih menunjukkan bahwa model pembelajaran kooperatif tipe Teams Games Tumamen (TGT) dapat meningkatkan hasil belajar matematika pada aspek kognitif dan psikomotor tetapi tidak meningkatkan hasil belajar pada aspek afektif. Sedangkan menurut Mulyati dan Guntarsih model pembelajaran kooperatif tipe Teams Games Turnamen (TGT) juga dapat meningkatkan hasil belajar matematika siswa karena dalam proses pembelajaran, siswa lebih termotivasi dan aktif. Nazamim juga menyatakan bahwa model pembelajaran kooperatif tipe Teams Games Turnamen (TGT) juga dapat meningkatkan hasil belajar matematika hingga 100\% dari jumlah subjek penelitiannya. Fida Rahmatika Hadi juga mengutarakan bahwa model pembelajaran kooperatif tipe Teams Games Turnamen (TGT) juga dapat meningkatkan hasil belajar matematika siswa, hal tersebut dapat dilihat dari hasil tes akhir siklus. Selain itu, Joeni Asih juga menunjukkan bahwa penggunaan model Teams Games Tumamen (TGT) dapat mempengaruhi aktivitas siswa menjadi lebih aktif, meningkatkan motivasi belajar siswa dan meningkatkan hasil belajar siswa. Berdasarkan beberapa penelitian di atas, dapat disimpulkan bahwa model pembelajaran kooperatif tipe Teams Games Tumamen (TGT) dapat meningkatkan hasil belajar matematika siswa Sekolah Dasar (SD).

Sedangkan hasil penelitian Özsoy dan Nazlı Yildi menunjukkan bahwa model pembelajaran menggunakan Learning Together (LT) dapat meningkatkan hasil belajar siswa Sekolah Dasar (SD), hal ini berdasarkan pada peningkatan yang signifikan nilai rata-rata kelas dibanding dengan model pembelajaran tradisional. Penelitian Unamba juga menunjukkan bahwa model pembelajaran Learning Together (LT) lebih efektif untuk meningkatkan hasil belajar siswa Sekolah Dasar (SD). Sedangkan penelitian Setianingsih menunjukkan bahwa siswa lebih aktif dalam kegiatan belajar mengajar dan mengalami peningkatan hasil belajar dengan menggunakan model pembelajaran kooperatif tipe Learning Together (LT). Penelitian Rahayu menunjukkan bahwa model pembelajaran kooperatif Learning Together (LT) dapat meningkatkan hasil dan prestasi belajar siswa. Hal ini terbukti dengan peningkatan ketuntasan belajar siswa dalam setiap siklus. Penelitian Irawati menunjukkan keefektifan model pembelajaran kooperatif Learning Together (LT) didasarkan pada uji keefektifan hasil belajar, sehingga Irawati menyimpulkan bahwa model pembelajaran tersebut lebih efektif dan dapat meningkatkan hasil belajar siswa. Berdasarkan penelitian-penelitian tersebut, dapat disimpulkan bahwa model pembelajaran kooperatif tipe Learning Together (LT) dapat meningkatkan hasil belajar matematika siswa Sekolah Dasar (SD). 
Berdasarkan uraian di atas, dapat disimpulkan bahwa model pembelajaran kooperatif tipe Teams Games Turnamen (TGT) dan Learning Together (LT) dapat meningkatkan hasil belajar matematika siswa Sekolah Dasar (SD). Hal tersebut dapat dilihat dari hasil hitungan yang diperoleh dari siklus yang dilakukan oleh penelitipeneliti sebelumnya. Meskipun hasil penelitian-penelitian sebelumnya memiliki hasil nilai yang berbeda.

\section{DAFTAR PUSTAKA}

Ali, M. (2009). Pendidikan Untuk Pembangunan Nasional, Menuju Bangsa Indonesia yang Mandiri dan Berbudaya Saing Tinggi. PT Imperial Bhakti Utama. Bandung. ISBN: 978-979-025-882-2.

Bukunola, J., \& Idowu, D. (2012). Effectiveness of Cooperative Learning Strategies on Nigerian Junior Secondary Students' Academic Achievement in Basic Science. British Journal of Education. 2 (3), 307-325.

Cahyaningsih. (2017). Pengembangan Model Pembelajaran Kooperatif Tipe Team Games Tournament (TGT) Terbadap Hasil Belajar Matematika Siswa SD. Jurnal Cakrawala Pendas, 3: 1.

Depdiknas. (2006). Kurikulum Tingkat satuan Pendidikan (KTSP) Untuk Sekolah Dasar/ MI. Jakarta: Terbitan Depdiknas.

Fathurrohman. (2015). Model-model Pembelajaran Inovatif. Jogjakarta: AR-RUZZ MEDIA.

Fida Rahmatika Hadi. (2017). Penerapan Model TGT (Teams Games Turnament) Dalam Pembelajaran Matematika Untuk Meningkatkan Hasil Belajar Siswa Kelas IV SDN Taman 3 Madiun. Skripsi diterbitkan. Madiun: FKIP Universitas PGRI Madiun.

Ginting, S.M., Hermansyah Amir. (2012). Penerapan Model Pembelajaran Somatis, Auditori, Visual danIntelektual (SAVI) Berbantuan Media Komputer Untuk Meningkatkan Kualitas Pembelajaran Kimia Fisik II. Exacta, 10(1): 98-105.

Hanggarwati, P. dkk. (2016). Penerapan Model Pembelajaran TGT Dengan Berbantuan Media Gambar Untuk. Meningkatkan Keaktifan dan Hasil Belajar IPA Kelas V SDN 1 Bitera. 6(3), hlm. 1-11.

Irawati, Eka. (2016). Keefektifan Model Pembelajaran Learning Together (LT) Terbadap Hasil Belajar Matematika Siswa Kelas IV SDN Gugus Bisma Kecamatan Somagede Kabupaten Banyumas. Skripsi. Universitas Negeri Semarang.

Joeni Asih tahun. (2017). Meningkatkan Motivasi Belajar Matematika Melalui Model Pembelajaran Kooperatif Tipe Teams Games Turnamen (TGT) Siswa kelas VI SD Negeri 02 Teluk Nilap Kubu Babussalam. Riau: FKIP Universitas Riau.

Johnson, D. W., Johnson, R. T., \& Holubec E. (1994). The New Circles of Learning: Cooperation in the Classroom and School. Alexandria, VA: Association for supervision and Curriculum Development.

Karli, H. dan Margaretha, S. Y. (2002). Implementasi Kurikulum Berbasis Kompetensi: Model-Model Pembelajaran. Bandung: Bina Media Informasi.

Kemendiknas. (2010). Bahan Belajar Mandiri Penilaian Hasil Belajar. Jakarta: Kemendiknas.

Lestari, I.A, Hermansyah Amir, Salastri Rohiat. (2017). Hubungan Persepsi Siswa Kelas X MIPA Di SMA Negeri Sekota Bengkulu Tahun Ajaran 2016/2017 Tentang Variasi Gaya Mengajar Guru Dengan Hasil Belajar Kimia. Alotrop, 1(2): 113-116.

Maisaroh, S. (2011). Upaya Peningkatkan Motivasi Dan Prestasi Belajar IPS Melalui Model Pembelajaran Kooperatif Tipe Teams Games Toumament. Jurnal Pendidikan Ekonomi Dinamika Pendidikan : 6(2): 150-169.

Mardodo, Budiyono dan Imam Sujadi. (2014). Implementasi Pembelajaran Kooperatif Model Think Pair Share Dan Learning Together Dengan Pendekatan Pembelajaran Matematika Realistik Ditinjau Dari Minat Belajar Siswa. Jurnal Elektronik Pembelajaran Matematika ISSN: 2339-1685 Vol.2, No.5, hal 513-524, Juli 2014. 
Medianty, S.U., Amrul Bahar, Elvinawati. (2018). Penerapan Model Discovery Learning Dengan Menggunakan Media Video Untuk. Meningkatkan Aktivitas Belajar Dan Hasil Belajar Siswa Kelas XI IPA 1 SMAN 1 Kota Bengkulu. Alotrop, 2(1): 58-65.

Mulyati dan Guntarsih. (2018). Meningkatkan Hasil Belajar Matematika Melahi Penerapan Model Pembelajaran Kooperatif Tipe TGT (Teams Games Tournaments) Pada Siswa Kelas V SDN Patrakomala Kota Bandung. Jurnal Cakrawala Pendas: 4: 1.

Nazamim. (2013). Penerapan model pembelajaran kooperatif tipe Teams Games Tournaments (TGT) untuk Meningkatkan Prestasi Belajar Matematika Siswa Kelas V MI Maarif Kediwnng Dlingo Bantul Tabun Pelajaran 2012/2013. UIN Sunan Kalijaga. Yogyakarta.

Nurhayati, H., Babang Robandi, Effy Mulyasari. (2018). Penerapan Model Pembelajaran Kooperatif Tipe TGT Untuk Meningkatkan Motivasi Belajar Siswa SD, Jurnal Pendidikan Guru Sekolah Dasar, 3(1): 1-12.

Özsoy, Nesrin dan Nazlı Yildi. (2014). The Effect Of Learning Together Technique Of Cooperative Learning Method On Student Achievement In Mathematics Teaching 7th Class OfPrimary School. Jurnal TOJET. Vol:3..No:3.Hal:4954.

Rahayu, Siti. (2015). Penerapan Metode Learning Together Untuk Peningkatan Prestasi Belajar Pecahan Pada Siswa Kelas III Semester Genap di SDN Petung 02 Sumberbaru Jember Tahun Pelajaran 2012/2013. Jurnal Pancaran.Vol:4.No:1.Hal:165-172.

Rahayu, Sri. dkk. (2015). Model Kooperatif Tipe Learning Together Untuk. Meningkatkan Kemampuan Komunikasi Matematis Siswa Sekolah Dasar. Jurnal Antologi. Vol: 3. No: 2.

Rachmadtullah, Reza, Via Yustitia, Bramianto Setiawan, Arif Mahya Fanny, Pana Pramulia, Wahyu Susiloningsih, Cholifah Tur Rosidah, Danang Prastyo, and Trio Ardhian. 2020. "The Challenge Of Elementary School Teachers To Encounter Superior Generation In The 4.0 Industrial Revolution: Study Literature." International Journal of Scientific \& Technology Research 9(4):1879-82.

Setiawan, Bramianto, Reza Rachmadtullah, and Vina Iasha. 2020. "Problem-Solving Method: The Effectiveness of The Pre-Service Elementary Education Teacher Activeness in The Concept of Physics Content." Jurnal Basicedu 4(4):1074-83.

Sanjaya, W. (2006). Strategi pembelajaran berorientasi pada proses. Jakarta: Fajar Interpratama Offset.

Setianingsih, Ani. (2010). Upaya Peningkatan Prestasi Belajar Matematika Materi Pokok FPB Dan KPK Melalui Learning Together Siswa Kelas VI Sekolah Dasar. E-Jurnal Dinas Pendidikan Kota Surabaya.Vol: 6.Hal:116.

Shoimin, A. (2014). 68 model pembelajaran inovatif dalam kurikulum 2013. Yogyakarta: Ar-ruzz Media.

Sidik,T.I., Mohammad Masykuri, Bakti Mulyani. (2016). Penerapan Model Pembelajaran Teams Games Toumament (TGT) Dilengkapi Adobe Flash Untuk Meningkatkan Aktivitas Dan Prestasi Belajar Siswa Pada Materi Kelarutan Dan Hasil Kali Kelarutan Kelas XI IP A Di SMA N 2 Boyolali Tabun Pelajaran 2014/2015. Jurnal Pendidikan Kimia (JPK), 5 (1): 41-45.

Simanjuntak, Salastri Rohiat, Elvinawati. (2017). Hubungan Antara Sarana Laboratorium Terbadap Ketrampilan Proses Sains Siswa Kelas XI MIPA 5 Di SMA Negeri 3 Kota Bengkulu. Alotrop, 1(2): 102-105.

Slavin R.E. (2011). Cooperative Learning Teori, Riset dan Praktik. Bandung: Nusa Media.

Slavin, R. E. (2009). Cooperative Learning (Teori, Riset, Praktik). Bandung: Nusa Media.

Slavin, R.E. (2010). Cooperative Learning Teori, Riset dan Praktik. Terj. Yusron, Narulita. Bandung: Nusa Media.

Slavin, Robert E. (2015). Cooperative Learning. Bandung: Nusa Media.

Suardi, M. (2018). Belajar \& Pembelajaran. Deepublish, ISBN: 9786024538637.

Sukayati. (2003). Media Pembelajaran Matematika Sekolah Dasar. Yogyakarta. Depdiknas. 
Suprijono, A. (2009). Cooperative Learning Teori \& Aplikasi P AIKEM. Yogyakarta: Pustaka Pelajar.

Syafitri, A., Hermansyah Amir, Elvinawati. (2019). Perbandingan Hasil Belajar Siswa Menggunakan Pembelajaran Kooperatif Tipe Team Games Toumament (TGT) Dengan Media Ular Tangga Dan Media Puzzle Di Kelas XI SMA Negeri 01 Bengkulu Tengah. Alotrop, 3(2): 132-138.

Syofiana, N. Salastri Rohiat, Hermansyah Amir. (2018). Perbandingan Hasil Belajar Siswa Menggunakan Model Pembelajaran Kooperatif Tipe Make A Match (MM) Dan Team Games Tournament (TGT) Pada Mata Pelajaran Kimia Di Kelas X IPA MAN 1 Kota Bengkulu. Alotrop, 2(2): 122 - 131.

Tim MKPBM. (2001). Strategi Pembelajaran Matematika Kontemporer. Bandung : UPI.

Tyasning, D.M., dkk. (2012). Penerapan Model Pembelajaran TGT (Teams Games Tournament) Dilengkapi LKS Untuk Meningkatkan Aktivitas dan Hasil Belajar Materi Minyak Bumi Pada Siswa Kelas X4 SMA Batik. 1 Surakarta Tabun Pelajaran 2011/2012. 1(1), hlm. 26-33.

Unamba, E.C. (2015). Effect of Learning-Together Technique on Pupils Achievement in Primary Mathematics. Jurnal Research in Education and Society.Vol:6.No:1.Hal:59-65.

Wardani, Sri. (2002). Pembelajaran Peecahan Masalab Matematika Melalui Model Kooperatif Tipe Jigsaw . Tesis UPI: Tidak Dipublikasikan.

Warli. (2013). Pembelajaran Matematika Realistik Materi Geometri Kelas IV MI. Journal Prospektus Jurnal Ilmiah UNIROW Tuban.

Yudianto, W.D., Kamin Sumardi, Ega T. Berman. (2014). Model Pembelajaran Teams Games Tournament Untuk Meningkatkan Hasil Belajar Siswa SMK, Journal of Mechanical Engineering Education. 2014: 1(2): 323-330.

Yunita, A., Salastri Rohiat, Hermansyah Amir. (2018). Analisis Kemampuan Berpikir Kritis Mata Pelajaran Kimia Pada Siswa Kelas XI IPA SMAN 1 Kepabiang. Alotrop, 2018: 2(1): 33-38. 